\title{
Growth, carcass characteristics, chemical composition and fatty acid profile of the longissimus dorsi muscle in goat kids fed diets with castor oil
}

\author{
Michelle de Oliveira Maia ${ }^{1}$, Ivanete Susin ${ }^{2}$, Alexandre Vaz Pires ${ }^{2}$, Renato Shinkai Gentil ${ }^{1}$, \\ Evandro Maia Ferreira ${ }^{1}$, Clayton Quirino Mendes ${ }^{1}$, Severino Matias de Alencar ${ }^{3}$
}

\author{
1 Programa de Pós-Graduação em Ciência Animal e Pastagem - ESALQ/USP, Piracicaba/SP, Brazil. \\ ${ }^{2}$ Departamento de Zootecnia - ESALQ/USP, Piracicaba/SP, Brazil. \\ ${ }^{3}$ Departamento de Agroindústria, Alimentos e Nutrição - ESALQ/USP.
}

\begin{abstract}
The objective in this study was to determine growth, carcass characteristics, chemical composition and fatty acid profile of the longissimus dorsi of crossbred Boer $\times$ Saanen kids fed castor oil. Twenty-four kids (12 males and 12 females) were assigned in a randomized complete block design with two treatments and twelve replications. Blocks were defined according to weight, gender and initial age of animals for the evaluation of performance. The experimental treatments consisted of two diets containing $900 \mathrm{~g}$ concentrate $/ \mathrm{kg}$ : a control diet (without addition of oil) and another containing castor oil at $30 \mathrm{~g} / \mathrm{kg}$ (on a dry matter basis). After they reached an average body weight of $25 \mathrm{~kg}$, males were slaughtered for the evaluation of carcass characteristics, chemical composition and fatty acid profile of the longissimus dorsi muscle. The addition of castor oil in the diet did not affect the intake of dry matter, crude protein and neutral detergent fiber; the average daily gain; and feed conversion, but increased the ether extract intake. No difference was observed for the carcass characteristics, chemical composition of the meat, concentration of C18:2 cis-9, trans-11 (CLA) and total concentration of saturated, monounsaturated and polyunsaturated fatty acids and their relations; however, there was increase in the concentrations of C18:2 trans-10, cis-12 (CLA) and C20:4 $\omega-6$. The addition of castor oil to the diet of crossbred Boer $\times$ Saanen kids containing a high content of concentrate did not promote benefit to the characteristics evaluated.
\end{abstract}

Key Words: conjugated linoleic acid, feedlot, lipid supplementation

\section{Introduction}

Goat meat consumption in Brazil, in spite of still being low, has been on the rise, mainly in large cities (Sousa, 2007). Goat meat is considered lean and contains more polyunsaturated fatty acids in comparison with meat from other ruminants (Banskalieva et al., 2000).

Different nutritional conditions may alter fatty acid composition in the muscles of ruminants. Lipid supplementation, in addition to promoting higher weight gain and better carcass composition due to the higher energetic density (Marinova et al., 2001), has been credited as one of the main factors to increase concentration of mono and polyunsaturated fatty acids, as well as the ratio between $\omega 6$ and $\omega 3$ families (Boles et al., 2005; Bas et al., 2007; Lewis et al., 2008).

Among the seed oils available, castor seed stands out for its high potential of oil production per surface unit in comparison with annual oilseeds (Barros et al., 2006), and also for its potential for cultivation in regions marginalized by the economic development. In addition to the easy adaptation to adverse climates, it is able to be successfully cultivated in several regions in the country (Oliveira et al., 2010). For these reasons, castor is considered an important oilseed for biodiesel production in Brazil.

Castor oil is comprised of approximately $80 \mathrm{~g}$ of ricinoleic fatty acid (acid 12-hydroxy-9-cis-octadecenoic)/ $100 \mathrm{~g}$ of oil. The hydroxyl group found in the carbon 12 of the ricinoleic acid gives the castor oil the exclusive property of solubility in alcohol and is also responsible for the lower oil rancidity, making it more attractive for animal consumption (Moshkin, 1986).

Castor oil does not contain ricin, a highly toxic protein that inactivates specifically and irreversibly eukaryotic ribosomes, once all seed protein remains in the meal after extraction and because it is an oil-insoluble protein (Severino, 2005).

Due to the lack of results of lipid supplementation in goat diets and the need for research to investigate the use of castor oil in ruminant diets, this study evaluated weight gain, carcass characteristics, chemical composition and fatty acid profile in the longissimus dorsi muscle of crossbred Boer $\times$ Saanen goats fed diets with castor oil. 


\section{Material and Methods}

This experiment was conducted at the Departamento de Zootecnia, Escola Superior de Agricultura "Luiz de Queiroz" (ESALQ), Universidade de São Paulo, Piracicaba, state of São Paulo, Brazil. Twenty-four crossbred Boer $\times$ Saanen goat kids (12 males and 12 females), with initial body weight of $13.4 \pm 2.0 \mathrm{~kg}$ at $66 \pm 4$ days of age were used.

Animals were confined for 56 days in individual indoor pens with concrete floor, feed bunks and water trough. Twelve pens were used for each treatment. The experimental treatments were composed of two diets: a control diet (no oil added) and another diet containing $30 \mathrm{~g}$ of castor oil $/ \mathrm{kg}$ of DM. Diets were formulated to be isonitrogenous (Table 1) and contained $100 \mathrm{~g}$ of roughage (coastcross hay) and $900 \mathrm{~g}$ concentrate $/ \mathrm{kg}$ of $\mathrm{DM}$, to meet the requirements of growing goats (NRC, 2007).

Corn was ground in a mill, characterizing a coarse grinding. Coastcross hay was coarsely chopped with the same mill equipped with a $1 \mathrm{~cm}$ pore sieve. All concentrate ingredients were previously weighed and homogenized in a horizontal Lucato ${ }^{\circledR}$ mixer with $500 \mathrm{~kg}$ capacity. Castor oil (Table 2) was weighed daily on an electronic scale with $5 \mathrm{~g}$ precision and mixed with the concentrate and hay prior to feeding.

The diet was offered daily ad libitum and approximately $100 \mathrm{~g}$ of refusals $/ \mathrm{kg}$ were allowed. Samples of each diet batch and a weekly ort aliquot of $100 \mathrm{~g} / \mathrm{kg}$ from each pen were collected. The samples were stored at $-18{ }^{\circ} \mathrm{C}$ for later laboratorial analyses. Diet samples and orts were processed in a Wiley mill equipped with a $1 \mathrm{~mm}$ sieve and analyzed to determine dry matter (DM), mineral matter (MM), and ether extract (EE) in accordance with the AOAC (2000).

Table 1 - Ingredients and chemical composition of the experimental diets $(\mathrm{g} / \mathrm{kg})$

\begin{tabular}{|c|c|c|}
\hline \multirow{2}{*}{ Ingredients } & \multicolumn{2}{|c|}{ Diets } \\
\hline & Control & Castor oil \\
\hline Coastcross hay & 100 & 100 \\
\hline Ground corn & 761 & 724 \\
\hline Soybean meal & 107 & 114 \\
\hline Castor oil & - & 30 \\
\hline Limestone & 12 & 12 \\
\hline Mineral premix $^{1}$ & 15 & 15 \\
\hline Ammonium chloride & 5 & 5 \\
\hline \multicolumn{3}{|l|}{ Chemical composition } \\
\hline Dry matter & 893 & 896 \\
\hline Crude protein & 146 & 146 \\
\hline Neutral detergent fiber & 211 & 206 \\
\hline Ether extract & 39 & 67 \\
\hline
\end{tabular}

Neutral detergent fiber (NDF) was determined with sodium sulfite and enzyme thermostable $\alpha$-amylase (Van Soest et al., 1991) using a fiber analyzer model ANKOM ${ }^{220}$ (ANKOM ${ }^{\circledR}$ Technology Corp.) as described in Holden (1999). The values obtained were corrected for ash after residue incineration. Total nitrogen determination was performed from sample combustion in a $\mathrm{LECO}^{\circledR}$ analyzer (Wiles et al., 1998), model FP 528 with combustion temperature of $835^{\circ} \mathrm{C}$. Crude protein content was obtained by multiplying the total nitrogen content by 6.25 .

To quantify the average daily gain (ADG), animals were weighed on days 0,28 and 56 of the experimental period, after a fasting period of 14 hours, on an electronic scale of $50 \mathrm{~g}$ accuracy.

When $25 \mathrm{~kg}$ of body weight (BW) was achieved, animals were weighed, after a 14-hour fasting period, to determine final body weight and slaughter body weight (SBW). After, males were slaughtered for determination of the carcass composition, subcutaneous fat thickness (SFT) over the 12th rib and longissimus muscle area (LMA). After slaughter and evisceration, carcasses were weighed to obtain the hot carcass weight ( $\mathrm{HCW}$ ). Carcasses were chilled for 24 hours at $4.0{ }^{\circ} \mathrm{C}$ in a controlled temperature room and weighed again for chilled carcass weight (CCW). To determine dressing percentage, chilled carcass yield (CCY) and shrink after chilling (SAC), the following formulas were used: Dressing percentage $=(\mathrm{HCW} / \mathrm{SBW}) \times$ $100 ; \mathrm{CCY}=(\mathrm{CCW} / \mathrm{SBW}) \times 100 ; \mathrm{SAC}=[(\mathrm{HCW}-\mathrm{CCW}) / \mathrm{HCW}]$ $\times 100$. After weighing, the cold carcasses were divided in two halves separated longitudinally, and the longissimus dorsi muscle was then exposed between the 12th and 13th ribs to determine SFT and LMA.

Longissimus dorsi muscle area and SFT were determined between the 12th and 13th ribs using a digital caliper (Battery, model SR44) graded in $\mathrm{mm}$. The longissimus dorsi muscle shape was traced on an acetate paper and the muscle area was determined by using a planimeter graded in $\mathrm{cm}^{2}$. These measurements were performed on the right and left sides of the carcass and the values represent their averages.

Table 2 - Castor oil fatty acid composition (g/100 g)

\begin{tabular}{lc}
\hline Fatty acid & $\mathrm{g} / 100 \mathrm{~g}$ \\
\hline C16:0 (palmitic) & 1.28 \\
C18:0 (estearic) & 2.06 \\
C18:1 (oleic) & 3.55 \\
C18:1-OH (ricinoleic) & 81.06 \\
C18:2 (linoleic) & 5.58 \\
C18:3 n3 (linolenic) & 0.50 \\
Others & 5.97 \\
\hline
\end{tabular}


After carcass assessment, the longissimus dorsi muscle from each left half-carcass was vacuumed, packaged and stored at $-18{ }^{\circ} \mathrm{C}$ for later determination of fatty acid composition, moisture, protein, ash and ether extract contents.

The moisture and ash contents were quantified according to the AOAC (2000). In addition, the protein determination was carried out based on the sample combustion using a LECO $^{\circledR}$ analyzer (Wiles et al., 1998), model FP 528, with combustion temperature regulated to $835^{\circ} \mathrm{C}$. Meat protein content was obtained by multiplying the total nitrogen content by 5.88 (Baldwin, 1995). The EE was obtained with LECO $^{\circledR}$ analyzer model TFE 2000, using compressed $\mathrm{CO}_{2}$ as solvent.

To determine meat fatty acid composition, a sample of approximately $2 \mathrm{~g}$, removed from the central part of the longissimus dorsi muscle, was used. The frozen sample was homogenized in $20 \mathrm{~mL}$ of a chloroform and methanol solution (2:1) using a Turrax homogenizer, disintegrator and emulsifier (Folch et al., 1957). In the next step, the lipid extract aliquot was methylated using the Kramer et al. (1997) method and stored at $-18{ }^{\circ} \mathrm{C}$ in amber flasks containing nitrogen to avoid oxidation.

Meat fatty acid composition was determined by gasliquid chromatography (GLC) using an Agilent equipment (7890-A, Agilent Technologies), with flame ionization detector (7683-B, Agilent Technologies) and a $100 \mathrm{~m}$ long and $250 \mu \mathrm{m}$ inner diameter capillary fused silica column (J \& W 112-88A7, Agilent Technologies) containing $0.20 \mu \mathrm{m}$ of cyanopropyl polysiloxane. Data were obtained with the software ChemStation (Agilent Tecnologies).

For fatty acid chromatograph separation, one microliter $(\mu \mathrm{L})$ of the sample was injected with a $10 \mu \mathrm{L}$ syringe in the split system at a 50:1 ratio. Hydrogen was used as carrier gas at a flow rate of $1.0 \mathrm{~mL} / \mathrm{min}$ and nitrogen was used as make-up with the output regulated to $30 \mathrm{~mL} / \mathrm{min}$. The synthetic air output was kept at $300 \mathrm{~mL} / \mathrm{min}$ and the temperatures in the injector and detector were 250 and $255^{\circ} \mathrm{C}$, respectively.
The initial temperature in the oven was $70^{\circ} \mathrm{C}$, gradually increased by $5{ }^{\circ} \mathrm{C} / \mathrm{min}$ until $100{ }^{\circ} \mathrm{C}$ and then held for 2 minutes. Afterwards, at a $10{ }^{\circ} \mathrm{C} / \mathrm{min}$ increase, the oven temperature reached $175{ }^{\circ} \mathrm{C}$ and was maintained for 40 minutes. In a third stage the temperature reached $225^{\circ} \mathrm{C}$ by a $5{ }^{\circ} \mathrm{C} / \mathrm{min}$ increase. Next, the oven temperature increased $20{ }^{\circ} \mathrm{C} / \mathrm{min}$ until a final temperature of $245{ }^{\circ} \mathrm{C}$. The total designated time for the analyses was 87.5 minutes.

Fatty acids were identified by comparing their retention times with the fatty acid methyl standards. A mix standard Supelco ${ }^{\circledR}$ (Sigma Aldrich) of 37 compounds and individual standards to identify fatty acids C18:1 trans-11, C18:2 cis-9, trans-11, C18:2 trans-10, cis-12 (Nu-Chek Prep, Inc.) and C18:1 - OH (Sigma Aldrich) were used.

The experimental design was of completely randomized blocks, and blocks were defined by weight, gender and initial age of animals. Data were analyzed using the PROC MIXED of SAS (Statistical Analysis System, version 9.0), adopting $\alpha=0.05$.

\section{Results and Discussion}

The use of castor oil in the diet did not affect $(\mathrm{P}>0.05)$ dry matter intake (DMI) (Table 3). Similar results were found for lambs fed different lipid sources in the diet (Manso et al., 2009; Homem Júnior et al., 2010). However, Solaiman et al. (2009) evaluated different amounts of cottonseed $(0 ; 157$ and $327 \mathrm{~g} / \mathrm{kg}$ of DM) in confined goat diets and found a quadratic effect for DMI.

The conflicting results obtained from the use of lipids in diets for ruminants cannot be attributed only to the type and amount of fat added, but also to the basal diet composition (Manso et al., 2009). In this study, $30 \mathrm{~g}$ of oil $/ \mathrm{kg}$ of DM were used and it should be considered that the EE in the control diet was $39 \mathrm{~g} / \mathrm{kg}$ of DM and in the diet with addition oil it was $67 \mathrm{~g} / \mathrm{kg}$ of DM. Normally, a DMI reduction is observed when the EE content in the diet is over $70 \mathrm{~g} / \mathrm{kg}$ of DM (Palmquist \& Jenkins, 1980).

Table 3 - Dry matter and ingredient intakes and performance of goat male kids fed diets with or without castor oil

\begin{tabular}{|c|c|c|c|c|}
\hline \multirow{2}{*}{ Item } & \multicolumn{2}{|c|}{ Diets } & \multirow{2}{*}{$\begin{array}{l}\text { Standard error of the } \\
\text { mean }\end{array}$} & \multirow{2}{*}{ P-value } \\
\hline & Control & Castor oil & & \\
\hline Dry matter intake (g/day) & 501.4 & 486.3 & 25.18 & 0.673 \\
\hline Dry matter intake $\left(\mathrm{g} / \mathrm{kgBW}^{0.75}\right)$ & 57.7 & 56.5 & 1.77 & 0.728 \\
\hline Crude protein intake $(\mathrm{g} / \mathrm{d})$ & 71.9 & 69.2 & 3.71 & 0.618 \\
\hline Neutral detergent fiber intake $(\mathrm{g} / \mathrm{d})$ & 112.5 & 107.6 & 5.15 & 0.516 \\
\hline Ether extract intake $(\mathrm{g} / \mathrm{d})$ & 19.3 & 33.0 & 2.04 & $<0.001$ \\
\hline Initial body weight $(\mathrm{kg})$ & 13.4 & 13.3 & 0.41 & 0.454 \\
\hline Average daily gain $(\mathrm{g})$ & 155.0 & 142.5 & 11.86 & 0.518 \\
\hline Final body weight (kg) & 21.36 & 21.23 & 0.82 & 0.861 \\
\hline Feed conversion (kg DMI/kg gain) & 3.47 & 3.33 & 0.11 & 0.561 \\
\hline
\end{tabular}

BW - body weight; DMI - dry matter intake. 
Moreover, castor oil is composed mainly of ricinoleic acid (Table 2), which, in spite of being a long-chain fatty acid (18 carbons), shows only one double bond in its structure, being therefore monounsaturated, which, in turn, when compared with medium-chain and longchain polyunsaturated fatty acids, is less toxic to ruminal microorganisms (Palmquist \& Mattos, 2006) and, thus, has less effect on DMI.

Intakes of crude protein $(\mathrm{CPI})$ and neutral detergent fiber (NDFI) were not affected $(\mathrm{P}>0.05)$ by the use of castor oil in the diet, probably because the diets were isonitrogenous and had similar fiber contents, in addition to the fact that DMI did not change. However, due to the oil addition, the EE intake increased $(\mathrm{P}<0.01)$ in the treatment with castor oil, which was expected due to the higher diet supplement.

The use of oil in the diet did not alter $(\mathrm{P}>0.05)$ the ADG of the goat kids. Therefore, their final weight was not changed $(\mathrm{P}>0.05)$. A weight gain in these animals was expected, once the diet with oil had higher energetic density and the DMI was not affected.

Due to the absence of effect on DMI and ADG, feed conversion ( $\mathrm{kg} \mathrm{DMI} / \mathrm{kg}$ gain) was not affected as well $(\mathrm{P}>0.05)$. Simitzis et al. (2008) found similar data using $1 \mathrm{~mL}$ of oregano oil per $\mathrm{kg}$ of concentrate fed to lambs. Likewise, Maia et al. (2010) evaluated the addition of $30 \mathrm{~g}$ of canola, sunflower and castor oils $/ \mathrm{kg}$ of DM in diets for lambs and found no changes in animal performance.

The use of castor oil did not influence $(\mathrm{P}>0.05)$ slaughter body weight of animals and, therefore, the hot carcass weight, chilled carcass weight, dressing percentage and chilled carcass yield did not change (Table 4).

Marinova et al. (2001) studied the use of sunflower oil ( $25 \mathrm{~g} / \mathrm{kg}$ of concentrate, as fed basis) in diets for goats and found no difference for carcass composition. However, the authors suggest that the use of oil in the diet could favor meat quality, once increase in the deposition and better fat distribution in the carcass was reported.

The chilled carcass yield values were similar to those found by Najafi et al. (2012), who reported chilled carcass yield of $43.33 \%$ when palm oil, soybean oil or fish oil were used in diets for Mahabadi goat kids.

The higher EE levels in the diets containing oil did not result $(\mathrm{P}>0.05)$ in higher deposition of subcutaneous fat. Likewise, Najafi et al. (2012) tested the use of palm oil, soybean oil or fish oil in the diet of Mahabadi kids and did not find difference for this variable, and the SFT average was higher than in this study, probably because of the heavier animals slaughtered $(33.9 \mathrm{~kg})$.

The diets did not affect $(\mathrm{P}>0.05)$ carcass cooling losses, probably due to the absence $(\mathrm{P}>0.05)$ of the SFT difference. Carcass back fat thickness can determine higher or lower cooling loss percentages, once it acts as a thermal insulator, protecting the carcasses against drying caused by cooling (Ribeiro et al., 2001).

The LMA measures aim to evaluate the animal muscle index, i.e., it is a measure that usually estimates the amount of muscle in the carcass. In this study, there was no effect of the treatment $(\mathrm{P}>0.05)$ on this variable, which is closely related to the absence of the castor oil effect on hot and cold carcass composition. Likewise, Marinova et al. (2001) did not find LMA difference in goats fed sunflower oil slaughtered at $20 \mathrm{~kg}$ of body weight, and the average found was $8.53 \%$ for the animals fed oil.

The use of $30 \mathrm{~g} / \mathrm{kg}$ of castor oil did not affect values of moisture, protein, ether extract and ash in goats (Table 5).

Data found for moisture, protein and ash are in accordance with those reported by Marinova et al. (2001) using $25 \mathrm{~g}$ of sunflower oil $/ \mathrm{kg}$ of concentrate DM and by Najafi et al. (2012), who evaluated the addition of $20 \mathrm{~g}$ of palm oil, soybean oil or fish oil $/ \mathrm{kg}$ of DM in goat kid diets.

The different fat extraction methods and even the variability of the same method among laboratories hamper the comparison of the values regarding fat content in the longissimus dorsi muscle.

The fatty acids identified at higher levels in the longissimus dorsi muscle of goats (Table 6) were C18:1, C16:0 and C18:0. In a review, Banskalieva et al. (2000) mentioned that values between 28 and $50 \mathrm{~g} / 100 \mathrm{~g}$ are found

Table 4 - Carcass characteristics of male goat kids fed diets with or without castor oil

\begin{tabular}{|c|c|c|c|c|}
\hline \multirow{2}{*}{ Item } & \multicolumn{2}{|c|}{ Diets } & \multirow{2}{*}{$\begin{array}{l}\text { Standard error of the } \\
\text { mean }\end{array}$} & \multirow{2}{*}{ P-valu } \\
\hline & Control & Castor oil & & \\
\hline Slaughter body weight $(\mathrm{kg})$ & 25.7 & 25.6 & 0.20 & 0.803 \\
\hline Hot carcass weight $(\mathrm{kg})$ & 12.1 & 12.3 & 0.13 & 0.423 \\
\hline Subcutaneous fat thickness (mm) & 0.7 & 0.6 & 0.06 & 0.446 \\
\hline Dressing percentage $(\mathrm{kg} / 100 \mathrm{~kg})$ & 47.3 & 48.2 & 0.66 & 0.452 \\
\hline Chilled carcass yield $(\mathrm{kg} / 100 \mathrm{~kg})$ & 45.0 & 45.8 & 0.63 & 0.455 \\
\hline
\end{tabular}


for $\mathrm{C} 18: 1 ; 15$ and $31 \mathrm{~g} / 100 \mathrm{~g}$ for $\mathrm{C} 16: 0$ and values between 6 and $17 \mathrm{~g} / 100 \mathrm{~g}$ for C18:0, so these fatty acids are found at higher levels in goat meat.

The use of castor oil in goat diets did not affect concentrations of total saturated, monounsaturated and polyunsaturated fatty acids. Similar response was found for concentration of fatty acid C18:2 cis-9, trans11(CLA); however, animals fed castor oil showed higher concentrations of C18:2 trans-10, cis-12 (CLA). Because ricinoleic acid $(\mathrm{C} 18: 1-\mathrm{OH})$ is found exclusively in castor oil, only the animals fed this oil showed this fatty acid.

In ruminants fed high concentrate diets, linoleic acid hydrogenation may be affected, favoring the formation of C18:2 trans-10, cis-12, which is reduced to C18:1 trans10 (Griinari \& Bauman, 1999). In the process, diets with a high concentrate content reduce ruminal $\mathrm{pH}$, which decreases lipolysis and biohydrogenation (Demeyer \& Doreau, 1999) and this last reaction may have been reduced in this study, given that an increase of CLA trans-10, cis-12 was found and no change was observed for C18:1 trans. This result shows that the ricinoleic acid did not favor the accumulation of this CLA isomer.
In this experiment, the peaks corresponding to C18:1 trans-10 and its isomer C18:1 trans-11 could not be differentiated; therefore, the peak was interpreted as C18:1 trans (Manso et al., 2009).

The data in this experiment are similar to those obtained by Bessa et al. (2007), where an increase in C18:2 trans-10 cis-12 was observed in lamb meat; however, the authors state that $\mathrm{C} 18: 2$ cis- 9 , trans-11 did not alter in response to the use of soy oil in diets with high concentrate. Beaulieu et al. (2002) and Gillis et al. (2004) evaluated the use of unsaturated fat in cattle fed diets with high concentrate and also reported increased CLA trans-10, cis-12 concentration, opposite to CLA cis-9 trans-11, which did not alter.

Castor oil increased the concentrations of long-chain fatty acid C20:4 $\omega-6$, which is synthesized from C18:2 $\omega-6$ through desaturation, chain elongation and new desaturation (Palmquist \& Mattos, 2006). Although no difference between C18:2 concentrations was detected in the different treatments, the meat from goats fed castor oil showed almost $20 \%$ more of this fatty acid in its composition, which possibly caused higher concentration of C20:4 $\omega-6$.

Table 5 - Chemical composition $(\mathrm{g} / 100 \mathrm{~g})$ of longissimus dorsi muscle from goat kids fed diets with or without castor oil

\begin{tabular}{lccccc}
\hline \multirow{2}{*}{ Item } & \multicolumn{3}{c}{ Diets } & Standard error of the & P-value \\
\cline { 2 - 3 } & Control & Castor & & 0.26 & 0.631 \\
Moisture & 75.0 & 74.8 & 20.7 & 0.47 & 0.472 \\
Protein & 20.4 & 1.5 & 0.11 & 0.680 \\
Ether extract & 1.6 & 0.9 & 0.02 & 0.976 \\
Ash & 0.9 & & & \\
\hline
\end{tabular}

Table 6 - Fatty acid composition (g/100 g of fatty acids) of longissimus dorsi muscle of goat kids fed diets with or without castor oil

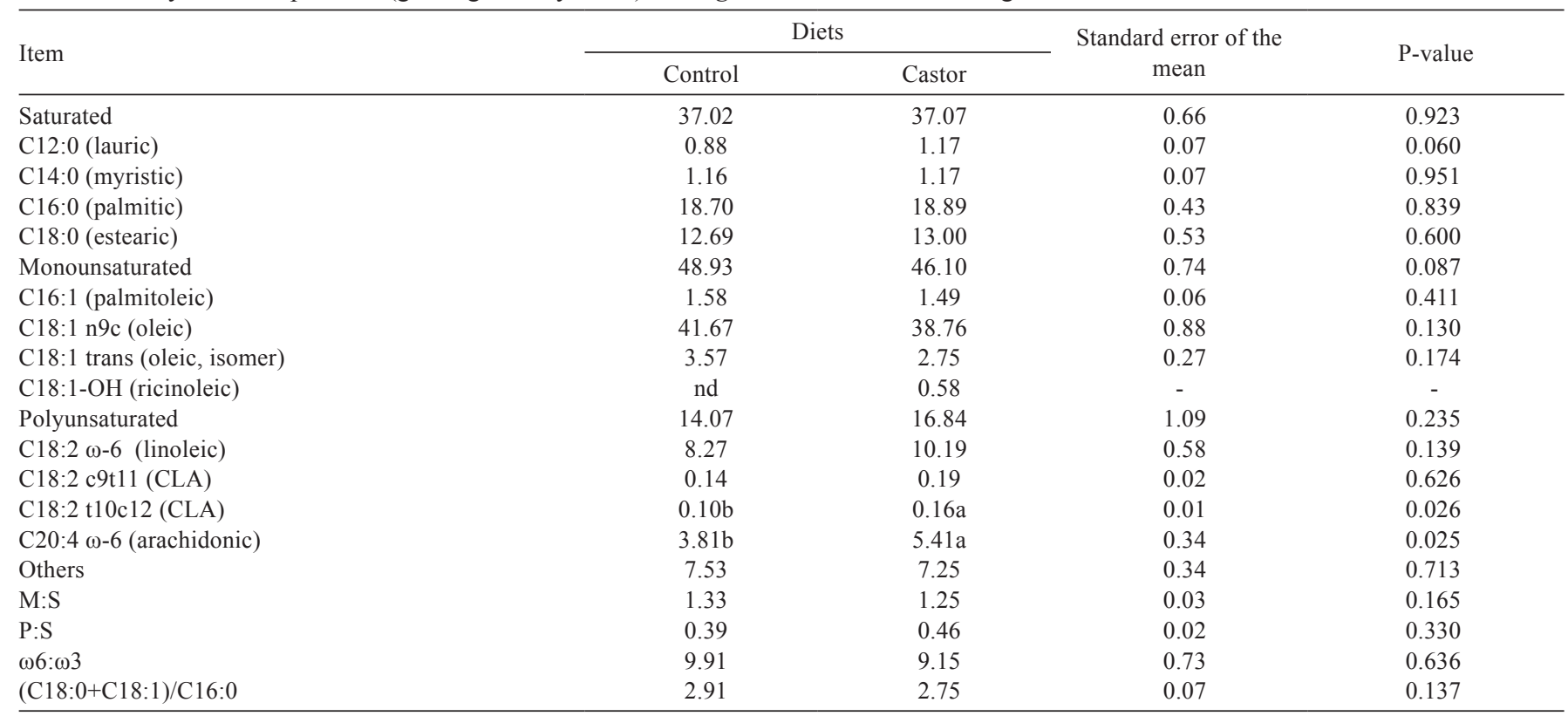

M:S - monounsaturated:saturated fatty acid ratio; P:S - polyunsaturated:saturated fatty acid ratio; $\omega 6: \omega 3$ - $\omega 6: \omega 3$ ratio; nd - not detected; CLA - conjugated linoleic acid. 
From a nutritional point of view, it is important to determine the ratio between concentrations of unsaturated and saturated fatty acids. Because of this, ratios and proportions between fatty acids of interest have been suggested as a way to evaluate food risk. Castor oil did not alter ratios between fatty acids $\mathrm{M}: \mathrm{S}, \mathrm{P}: \mathrm{S}, \omega 6: \omega 3$ or (C18:0+C18:1)/C16:0.

According to Wood et al. (2003), the Health Department of the United Kingdom recommends a P:S ratio higher than 0.4 and $\omega 6: \omega 3$ lower than 4 for beneficial effects against coronary diseases and even cancer.

The values for $\omega 6: \omega 3$ ratio found in this study are above the recommendation stated by Wood et al. (2003). The high values found for this ratio in this study is possibly attributed to the high quantity of grains in the diet, which in turn are rich in fatty acids of the $\omega 6$ family (Bessa et al., 2007). According to Wood et al. (2003), ruminant meat may contain low $\omega 6: \omega 3$ ratio when animals consume grass with a high C18:3 content. Talpur et al. (2008) evaluated the composition of fatty acids in goats finished on pasture and found an average $\omega 6: \omega 3$ ratio of 3.38 .

Considering that oleic fatty acid (C18:1) decreases the cholesterol level in the blood, while palmitic fatty acid (C16:0) increases it and that stearic acid (C18:0) has no influence (Rhee et al., 2000), it is important to analyze the behavior of these three fatty acids.

Therefore, the $(\mathrm{C} 18: 0+\mathrm{C} 18: 1) / \mathrm{C} 16: 0$ ratio could possibly better describe the effects of different fatty acids on human health. The values found in this study for this ratio were 2.91 and 2.75 for the control and castor oil treatments, respectively, thus corroborating the data found in the review carried out by Banskalieva et al. (2000), which are between 2 and 3 for goat meat.

\section{Conclusions}

The use of $30 \mathrm{~g}$ of castor oil $/ \mathrm{kg}$ of diet DM for confined Boer $\times$ Saanen goat kids fed high-concentrate diet does not promote benefits to weight gain, carcass quantitative characteristics, chemical composition and fatty acid profile in the longissimus dorsi muscle.

\section{References}

ASSOCIATION OF OFFICIAL ANALYTICAL CHEMISTS AOAC. Official methods of analysis, 19.ed. Washington, D.C., 2000. 1219 p.

BALDWIN, R.L. Energy requirements for maintenance and production. In: Baldwin, R.L. (Ed.) Modeling ruminant digestion and metabolism. London: Chapman and Hall, 1995. p.148-188.
BANSKALIEVA, V.; SAHLU, T.; GOETSCH, A.L. Fatty acid composition of goat muscles and fat depots - a review. Small Ruminant Research, v.37, p.255-268, 2000.

BARROS, G.S.C.; SILVA, A.P.; PONCHIO, L.A. et al. Custos de produção de biodisel no Brasil. Revista de Política Agrícola, v.15, p.36-50, 2006.

BAS, P.; BERTHELOT, V.; POTTIER, E. et al. Effect of level of linseed on fatty acid composition of muscles and adipose tissues of lambs with emphasis on trans fatty acids. Small Ruminant Research, v.77, p.678-688, 2007.

BEAULIEU, A.D.; DRACKLEY, J.K.; MERCHEN, N.R. Concentrations of conjugated linoleic acid (cis-9, trans-11octadecadienoic acid) are not increased in tissue lipids of cattle fed a high-concentrate diet supplemented with soybean oil. Journal of Animal Science, v.80, p.847-861, 2002.

BESSA, R.J.B.; ALVES, S.P.; JERÒNIMO, E. et al. Effect of lipid supplements on ruminal biohydrogenation intermediates and muscle fatty acids in lamb. European Journal of Lipid Science and Technology, v.109, p.868-883, 2007.

BOLES, J.A.; KOTT, R.W.; HATFIELD, P.G. et al. Supplemental safflower oil affects the fatty acid profile, including conjugated linoleic acid of lamb. Journal of Animal Science, v.83, p.2175-2181, 2005.

DEMEYER, D.; DOREAU, M. Targets and procedures for altering ruminant meat and lipids. Proceedings of the Nutrition Society, v.58, p.593-607, 1999.

FOLCH, J.; LEES, M.; STANLEY, G.H.S. A simple method for the isolation and purification of total lipids from animal tissues. The Journal of Biological Chemistry, v.226, p.497-509, 1957.

GILLIS, M.H.; DUCKETT, S.K.; SACKMANN, J.R. Effects of supplemental rumen-protected conjugated linoleic acid or corn oil on fatty acid composition of adipose tissues in beef cattle. Journal of Animal Science, v.82, p.1419-1427, 2004.

GRIINARI, J.M.; BAUMAN, D.E. Biosynthesis of conjugated linoleic acid and its incorporation into meat and milk in ruminants. In: YURAWECZ, M.P.; MOSSOBA, M.M.; KRAMER, J.K.G. et al. (Eds.). Advances in conjugated linoleic acid research. Champaign: AOCS Press, 1999. 1v, p.180-200.

HOLDEN, L.A. Comparison of methods of in vitro dry matter digestibility for ten feeds. Journal of Dairy Science, v.82, p.1791-1794, 1999.

HOMEM JUNIOR, A.C.; EZEQUIEL, J.M.B.; FÁVARO, V.R. et al Fermentação ruminal de ovinos alimentados com alto concentrado e grãos de girassol ou gordura protegida. Arquivo Brasileiro de Medicina Veterinária e Zootecnia, v.62, p.144-153, 2010.

KRAMER, J.K.G.; FELLNER, V.; DUGAN, M.E.R. et al. Evaluating acid and base catalysts in the methylation of milk and rumen fatty acids with special emphasis conjugated dieno and total trans fatty acids. Lipids, v.32, p.1219-1228, 1997.

LEWIS, G.S.; WULSTER-RADCLIFFE, M.C.; HERBEIN, J.H. Fatty acid profiles, growth, and immune responses of neonatal lambs fed milk replacer and supplemented with fish oil or safflower oil. Small Ruminant Research, v.79, p.167-173, 2008.

MAIA, M.O; SUSIN, I.; NOLLI, C.P. et al. Desempenho de cordeiros mestiços Dorper x Santa Inês alimentados com óleo de canola, girassol ou mamona. In: CONGRESSO NORDESTINO DE PRODUÇÃO ANIMAL, 4., 2010, Mossoró. Anais eletrônicos... Mossoró: Universidade Federal Rural do Semi Árido, 2010. (CD-ROM).

MANSO,T.; BODAS, R.; CASTRO, T. et al. Animal performance and fatty acid composition of lambs fed with different vegetable oils. Meat Science, v.83, p.511-516, 2009.

MARINOVA, P.; BANSKALIEVA, V.; ALEXANDROV, S. et al. Carcass composition and meat quality of kids fed sunflower oil supplemented diet. Small Ruminant Research, v.42, p.219-227, 2001.

MOSHKIN, V.A. Castor. New Delhi: Oxonian Press, 1986. 315p.

NACIONAL RESEARCH COUNCIL - NRC. Nutrient requirements of small ruminants: sheep, goats, cervids and new world camelids. Washington, D.C., 2007. 384p. 
NAJAFI, M.H.; ZEINOALDINI,S.; GANJKHANLOU, M. et al. Performance, carcass traits, muscle fatty acid composition and meat sensory properties of male Mahabadi goat kids fed palm oil, soybean oil or fish oil. Meat Science, v.92, p.848-854, 2012.

OLIVEIRA, A.S.; PINA, D.S.; CAMPOS, J.M.S. Co-produtos do biodiesel na alimentação de ruminantes. In: SIMPÓSIO SOBRE MANEJO ESTRATÉGICO DA PASTAGEM, 5., SIMPÓSIO INTERNACIONAL SOBRE PRODUÇÃO ANIMAL EM PASTEJO, 3., 2010, Viçosa, MG. Anais... Viçosa, MG: UFV, 2010. p.419-462.

PALMQUIST, D.L.; JENKINS, T.C. Fat in lactation ration: review. Journal of Dairy Science, v.63, p.1-14, 1980.

PALMQUIST, D.L.; MATTOS, W.R.S. Metabolismo de lipídeos. In: BERCHIELLI, T.T.; PIRES, A.V.; OLIVEIRA, S.G. (Eds.) Nutrição de ruminantes. Jaboticabal: FUNEP, 2006. Cap.10, p.287-310.

RHEE, K.S.; WALDRON, D.F.; ZIPRIN, Y.A. et al. Fatty acid composition of goat diets $v s$ intramuscular fat. Meat Science, V.54, p.313-318, 2000.

RIBEIRO, T.R.; PEREIRA, J.C.; OLIVEIRA, M.V.M. et al. Características da carcaça de bezerros holandeses para produção de vitelos recebendo dietas com diferentes níveis de concentrado. Revista Brasileira de Zootecnia, v.30, p.2154-2162, 2001.

SEVERINO, L.S. O que sabemos sobre a torta de mamona. Campina Grande: Embrapa Algodão, 2005. 31p. (Documentos, 134).
SIMITZIS, P.E.; DELIGEORGIS, S.G.; BIZELIS, J.A. et al. Effect of dietary oregano oil supplementation o lamb meat characteristics. Meat Science, v.79, p.217-223, 2008.

SOLAIMAN, S.G.; GURUNG, N.K.; MCCRARY, Q. et al. Feeding performance and blood parameters of male goat kids fed EasiFlo ${ }^{\circledR}$ cottonseed. Small Ruminant Research, v.81, p.137-145, 2009.

SOUSA, W.H. O agronegócio da caprinocultura de corte no Brasil. Tecnologia e Ciência Agropecuária, v.1, p.51-58, 2007.

TALPUR, F.N.; BHANGER, M.I.; SHERAZI, S.T.H. Intramuscular fatty acid profile of longissimus dorsi and semitendinosus muscle from Pateri goats fed under traditional feeding system of Sindh, Pakistan. Meat Science, v.80, p.819-822, 2008.

VAN SOEST, P.J.; ROBERTSON, J.B.; LEWIS, B.A. Methods for dietary fiber, neutral detergent fiber, and nonstarch polysaccharides in relation to animal nutrition. Journal of Dairy Science, v.74, p.3583-3597, 1991.

WILES, P.G.; GRAY, I.K.; KISSLING, R.C. Routine analysis of proteins by Kjeldahl and Dumas methods: review and interlaboratory study using dairy products. Journal of AOAC International, v.81, p.620-632, 1998.

WOOD, J.D.; RICHARDSON, R.I.; NUTE, G.R. et al. Effects of fatty acids on meat quality: a review. Meat Science, v.66, p.21-32, 2003. 